\title{
Diachronic Narratology. (The Example of Ancient Greek Narrative)
}

Irene J. F. de Jong

Created: 4. September 2013 Revised: 24. January 2014

\section{Definition}

Diachronic narratology means the description and analysis of the history of the forms and functions of narrative devices within a given (period of a) literature.

\section{Explication}

An explicit plea for the diachronization of narratology was launched by Fludernik ( 2003), although before her others, e.g. Pavel (1996), had in actual practice combined literary history and structuralist analysis. With this term, Fludernik does not mean the historiography of narratology itself, i.e. the history of the development of theoretical concepts, but the history of the actual use made by authors of narrative devices. What is the history of the first-person novel, of narratorial comments, of audience-address, of the locus amoenus, etc.? Some narrative devices have long been identified and studied, such as mimesis, the Muse, or openings, but narratology has brought together, systematised, and much expanded the number of narrative devices found employed by authors in narrative texts, and thereby opened the way to the study of their use over time.

\section{History of the Concept and its Study}

\subsection{From Synchronic to Diachronic Narratology}

Classical narratology, a product of formalism and structuralism, almost is by definition synchronically rather than diachronically oriented. Its interest is the narrator in the text rather than the historical author producing that text, the narratees rather than flesh-and-blood readers, and the common signifying structures of narratives across time and space. Thus early narratology could perhaps be called 'achronic' rather than synchronic: it explicitly tried to elide extratextual time and historical context in order to find the common ground of all narratives and get away from the traditional biographical fashion of literary 
criticism. As a result, there was for a long time, as Fludernik (2003: 331) noted, "comparatively little interest on a theoretical level in the history of narrative forms and functions."

Of course, there always have been narratological studies with historical dimensions. We may think here of Booth ([1961] 1983), which deals with the shift from overt to covert narrators in the 19th century; Romberg (1962), which discusses first-person novels from different countries and ages; or Scholes and Kellogg ([1968] 2006), which includes historical studies on point of view, plot, and character in European narrative from antiquity onwards. And of course, before the advent and spread of narratology, classic historical studies on aspects of narrative were written e.g. by Auerbach ([1946] 2003), who deals with the representation of reality in European narrative, or Curtius ([1948] 1953), who traces the continuity of a.o. narrative devices like the Muse from Classical Latin via Medieval Latin into modern European literatures.

But what put diachrony more emphatically on the agenda in the 1990s were, according to Fludernik (2003: 332), feminist narratology, the application of narratology to historical texts, and research into the origins of the novel. As an example of diachronic narratology, she discusses the handling of scene shifts in a corpus of some fifty texts of British literature between the late medieval period and the early 20th century. In her conclusion she notes that "the scene shift was ideally suited to demonstrate that formal analysis needs to be complemented by a functional approach [...] a function can be superseded and its former expressions still used for new purposes" (344).

At about the same time that Fludernik was launching the idea of diachronic narratology, de Jong started-independently_editing a history of ancient Greek narrative. The need for such a history arises from the fact that while there are many histories of Greek drama, historiography, rhetoric, or literary criticism, "the history of ancient Greek narrative is as yet untold" (de Jong et al., eds. 2004: xi).

This history appears in a series of volumes entitled "Studies in ancient Greek narrative" (SAGN). The historical approach offers, for the first time, a major example of diachronic narratology in that it traces the history of various narrative devices for one literature in its entirety. In the case of ancient Greek literature, this covers a time span of twelve centuries ( 800 BC to 400 AD). So far, three volumes have appeared: on narrators, narratees, and narratives (de Jong et al., eds. 2004), on time (de Jong \& Nünlist, eds. 2007), and on space (de Jong, ed. 2012). A fourth volume, on characterization, is currently in progress. The narrative devices discussed include overt versus covert narrators or narratees, primary versus secondary narrators and narratees, second-person narration, embedded narratives, 
analepsis and prolepsis, singulative, iterative and scenic narration, retardation, acceleration, setting versus frame, focalised space, description and ekphrasis, the thematic, symbolic, and psychological functions of space. The series is aimed at a larger readership than the community of classicists, and thus all passages are discussed in translation.

\subsection{A History of Ancient Greek Narrative as an Example of Diachronic Narratology}

\subsubsection{Defining Ancient Greek Narrative}

When writing a history of narrative devices, the first question to answer is what actually constitutes a narrative in the literature under discussion. For SAGN, the following texts of ancient Greek literature have been included: purely narrative genres (epic, novel); what could be called applied narrative genres (historiography, biography, philosophy); narratives embedded in non-narrative genres (the mythological parts of lyric, hymn, and pastoral; the prologue and messengerspeeches of drama; the narrationes of oratory); and what Genette ([1972] 1980: 236-37) called pseudo-diegetic narratives, i.e. narratives with a suppressed narrator. He used this term in explicit reference to Plato's philosophical dialogue Theaetetus $143 \mathrm{c}$, where the narrator says that he avoids the tag "and he said." In addition to Plato's dialogues, we can think of the so-called mimetic Idy/s of Theocritus and the Eclogues of Virgil, poems that consist entirely of dialogue but that belong to genres that also have instances with a narrative frame and a narrator.

To modern eyes, this corpus may seem both broad and restricted. It is broad in that it includes philosophy and historiography, text-types which nowadays are not necessarily in narrative form and would not normally be included in a literary history. However, it should be borne in mind that philosophy in antiquity usually takes the form of narrated dialogues. As for ancient historiography, this was invariably in narrative form due to the fact that the genre's pedigree traces back to epic (cf. Strasburger 1972). It confirms Genette's ([1991] 1993) and Cohn's (1999) contention that historiography falls within the domain of narratology. At the same time, it contradicts Cohn's call for a separate historiographic narratology: in antiquity the same devices are found in semi-historical epic, historiography, and in the fictional novel.

The SAGN corpus is restricted in that only narratives embedded in lyric and drama are included. Recently, some narratologists have argued that drama and lyric as a whole should be considered forms of narrative (see e.g. Jahn 2001; Hühn \& Kiefer 2005; Hühn \& Sommer $\rightarrow$ Narration in Poetry and Drama [1]). In SAGN, however, the presence of a narrator is taken as the defining element of a narrative. 


\subsubsection{Form and Function of Narrative Devices}

One of the central research questions of diachronic narratology is that of the relationship between form and function: how does one and the same device acquire ever new functions, depending on the exigencies of a genre, the predilections of an author, the theme of the narrative, or the taste of an age?

Since the greater part of ancient Greek narrative deals with the same mythological stories time and again, a beginning in medias res works differently in such a narrative whose content is largely known to the narratees (e.g. the Odyssey) than it does in a purely fictional text like Heliodorus' Aethiopica. Anticipating the death of a hero may have a tone which is tragic (Iliad: Patroclus), moralistic (Odyssey: the suitors) or revengeful (Herodotus' Histories). Drawing in the past in the form of external analepses may have a purely informative function (Homer: Iliad) or it may serve ideological purposes, the past being inserted for comparative reasons (Thucydides' Peloponnesian War or Plutarch's Biographies). The anachronical order in which many mythological stories are told in Greek literature (a narrator starts in the present, returns step by step to the past and then proceeds in chronological order back to the present) began as an oral device in Homer but was put to highly sophisticated use by Pindar and Sophocles in their lyric narratives. Greek literature has a long history of charging details of spatial setting with (ever-changing) semantic significance: thus when Plato for once situates one of his philosophical dialogues outside the city of Athens in the countryside (the Phaedrus), this setting has all the characteristics of a locus amoenus (trees, water, shade, a breeze); such a décor is typically the place for love-making, but is now refunctionalised to become the setting for a philosophical talk about love.

\subsubsection{Genres and Development}

In ancient Greek narrative the use of narrative devices is not genre-bound: historians use epic devices, tragedians use historiographical devices, orators use tragic devices, and so on. This phenomenon can perhaps be explained as the result of genres being only loosely defined in ancient Greek literature (see e.g. Depew \& Obbink, eds. 2000), but it also indicates the tendency of narrative devices to be universal. What can change, of course, is the function a device acquires in a given genre (see previous section).

The history of ancient Greek narrative makes clear that literature need not necessarily develop in an evolutionary sense, i.e. in the form of a primitive origin slowly evolving towards ever more sophistication and complexity. Greek literature starts with a 'big bang', namely the Homeric epics with their incredibly rich and subtle exploitation of the potential of narrative, and ends with often rather simplistic 
novels. A caveat here is that for us, Homer's texts are the first in ancient Greek literature, but that they were in fact preceded by innumerable oral predecessors whose texts have not come down to us, so that Homer was not really the first. There is also the intriguing issue of the indebtedness of early Greek literature to Near Eastern literature (see e.g. West 1997; Haubold 2013). But even taking these two observations into account, it is noteworthy that the text which is the fountainhead of all ancient (and much later European) narrative comes so early in history.

\subsubsection{Narratology and (Oral) Poetry}

Narratology has developed primarily in connection with the novel and hence with prose narrative. In classics, however, narratological studies took poetry, especially epic poetry, into account from an early stage onwards (e.g. Fusillo 1985; de Jong [1987] 2004, 2001; Richardson 1990). Poets such as Homer, Hesiod, Apollonius of Rhodes, Callimachus, Pindar, Bacchylides, the three tragedians Aeschylus, Sophocles, Euripides, the comedian Aristophanes, and Theocritus all form a vital part of the history of Greek narrative art. Indeed, it was a poet, Homer, who developed most of the classical narrative toolkit: the Muses, the in medias res technique, prolepsis and analepsis, embedded focalization, or the tale within the tale. Later prose authors took over and carried on with what was originally developed by this poet. The differences between poetic and prose narrative seem to lie more at the level of stylistics: poetry uses more epithets, metaphors, similes, etc.

When dealing with orality, narratology has focused on fairytales (mostly in written transcription) or on conversational narration (Fludernik $\rightarrow$ Conversational Narration Oral Narration [2]). Once again, the Homeric epics, be they oral texts or texts still very close to oral traditions (on this much debated issue, see e.g. the overview in Amodio 2005), provided rich material for narratology. For instance, the repetition of words, lines, and scenes, a hallmark of oral poetry, can be well understood and appreciated in Homer when analysed in terms of the narratological category of rhythm (de Jong 1991). This oral text has exercised a tremendous influence on all later, written literature, and the unbroken continuum of orality is a telling harbinger for the principle of intermediality in narrative. Whereas narratologists, dealing mainly with modern literature, look for intermediality in the new media of our present age (e.g. Ryan, ed. 2004; Ryan $\rightarrow$ Narration in Various Media [3]), ancient Greek literature also provides much fascinating material in this area. The Homeric epics were oral in that they were composed orally and listened to, while many other texts were aural, i.e. written by their author but listened to by their consumers rather than read: the lyrics of Sappho and Pindar, the narratives of Greek drama, and the many speeches of orators like Lysias or Demosthenes. Even when ancient Greek narrative was written, it often still breathed a spirit of orality in the form of 
'fingierte Mündlichkeit', either because writing was deemed suspect (in the time of the historian Herodotus) or because of the strength of tradition (the extremely bookish epic narrator Apollonius of Rhodes posing as a bard in order to resemble his venerated model Homer).

\section{Topics for Further Investigation}

One of the areas calling for further reflection and investigation is how exactly we are to evaluate the results of diachronic narratology. What are we observing when we see different authors using the same narrative device across time and space? Can we indeed draw up a history, or should we be content with making a typological comparison? Can we consider such correspondences a form of narratological intertextuality, i.e. can we imagine author $X$ consciously following the example of author $Y$, or should we rather think in terms of narrative universals, i.e. assume that different authors may employ the same device independently? Or should we allow for both possibilities?

The first option would seem to be a priori plausible in the literature of ancient Greece where, as in Roman literature, imitatio and aemulatio were key concepts, where all authors up until the Hellenistic era were telling roughly the same mythological stories, and where its main canonical text, the Homeric epics, provided most of the narrative tricks of the trade.

But what about diachronic narratology on a larger scale which would discuss resemblances in narrative technique between neighbouring literatures (e.g. the Greek and Near Eastern literatures of 1600-700 BC) or succeeding literatures (such as classical, medieval, and modern European literatures)? Can we still draw historical lines here and, if so, how should we imagine this to have worked in practice? Do authors pick up their narrative devices from other texts, or are they somehow present in a culture in the form of memes? Some first tentative thoughts on these matters are developed in de Jong (2014a and 2014b).

\section{Bibliography}

\subsection{Works Cited}

Amodio, Mark C., ed. (2005). New Directions in Oral Theory. Tempe: Arizona Center for Medieval and Renaissance Studies.

Auerbach, Erich ([1946] 2003). Mimesis, the Representation of Reality in Western Literature. Princeton: Princeton UP. Booth, Wayne ([1961] 1983). The Rhetoric of Fiction. Chicago: Chicago UP. 
Cohn, Dorrit (1999). The Distinction of Fiction. Baltimore: Johns Hopkins UP. Curtius, Ernst R. ([1948] 1953). European Literature and the Latin Middle Ages. Princeton: Princeton UP.

Depew, Mary \& Dirk Obbink, eds. (2000). Matrices of Genre. Authors, Canons, and Society. Cambridge: Harvard UP.

Fludernik, Monika (2003). "The Diachonization of Narratology." Narrative 11, 331-48. Fusillo, Massimo (1985). Il tempo delle Argonautiche. Un analisi del racconto in Apollonio Rodio. Roma: Edizioni dell'Ateneo.

Genette, Gérard ([1972] 1980). Narrative Discourse. An Essay in Method. Ithaca: Cornell UP.

Genette, Gérard ([1991] 1993). Fiction \& Diction. Ithaca: Cornell UP. Haubold, Johannes (2013). Greece and Mesopotamia: Dialogues in Literature. Cambridge: Cambridge UP.

Hühn, Peter \& Jens Kiefer (2005). The Narratological Analysis of Lyric Poetry: Studies in English Poetry from the $16^{\text {th }}$ to the $20^{\text {th }}$ Century. Berlin: de Gruyter. Jahn, Manfred (2001). "Narrative Voice and Agency in Drama: Aspects of a Narratology of Drama." New Literary History 32, 659-79.

Jong, Irene J. F. de ([1987] 2004). Narrators and Focalizers. The Presentation of the Story in the Iliad. London: Duckworth.

Jong, Irene J. F. de (1991). "Narratology and Oral Poetry: The Case of Homer." Poetics Today 12, 405-23.

Jong, Irene J. F. de (2001). A Narratological Commentary on the Odyssey.

Cambridge: Cambridge UP.

Jong, Irene J. F. de (2014a). "After Auerbach. Ancient Greek Literature as Test Case of European Literary Historiography." European Review 22,116-28.

Jong, Irene J. F. de (2014b). "The Anonymous Traveller in European Literature: a Greek Meme?" D. Cairns \& R. Scodel (eds.). Defining Greek Narrative. Edinburgh: Edinburgh UP, 314-33.

Jong, Irene J. F. de et al., eds. (2004). Narrators, Narratees, and Narratives in Ancient Greek Literature. Studies in Ancient Greek Narrative 1. Leiden: Brill. Jong, Irene J. F. de \& René Nünlist, eds. (2007). Time in Ancient Greek Literature. Studies in Ancient Greek Narrative 2. Leiden: Brill.

Jong, Irene J. F. de, ed. (2012). Space in Ancient Greek Literature. Studies in Ancient Greek Narrative 3. Leiden: Brill.

Pavel, Thomas (1996). L'art d'éloignement. Essai sur l'imagination classique. Paris: Gallimard.

Richardson, Scott (1990). The Homeric Narrator. Nashville: Vanderbilt UP. Romberg, Bertil (1962). Studies in the Narrative Technique of the First-Person Novel. Stockholm: Almqvist \& Wiksell.

Ryan, Marie-Laure, ed. (2004). Narrative across Media: The Languages of Storytelling 
. Lincoln: U of Nebraska P.

Scholes, Robert \& Robert Kellogg ([1968] 2006). The Nature of Narrative. Fortieth Anniversary Edition. New York: Oxford UP.

Strasburger, Herman (1972). "Homer und die Geschichtsschreibung." Studien zur Alten Geschichte, Bd ii. Hildesheim: Georg Olms, 1057-97.

West, Martin L. (1997). The East Face of Helicon: West Asiatic Elements in Greek Poetry and Myth. Oxford: Oxford UP.

\subsection{Further Reading}

Fusillo, Massimo (1991). Naissance du roman. Paris: Seuil.

Grethlein, Jonas (2006). Das Geschichtsbild der Ilias. Eine Untersuchung aus phänomenologischer und narratologischer Perspektive. Göttingen: Vandenhoeck and Ruprecht.

Grethlein, Jonas \& Rengakos, Antonios, eds. (2009). Narratology and Interpretation: The Content of Narrative Form in Ancient Literature. Berlin: de Gruyter. Lowe, Nick J. (2000). The Classical Plot and the Invention of Western Narrative. Cambridge: Cambridge UP.

Wheeler, Stephen M. (1999). A Discourse of Wonders: Audiences and Performances in Ovid's Metamorphoses. Philadelphia: U of Pennsylvania P. Winkler, Jack J. (1985). Auctor and Actor: A Narratological Reading of Apuleius' The Golden Ass. Berkeley: U of California P.

To cite this entry, we recommend the following bibliographic format:

de Jong, Irene J. F.: "Diachronic Narratology. (The Example of Ancient Greek Narrative)". In: Hühn, Peter et al. (eds.): the living handbook of narratology. Hamburg: Hamburg University. URL = http://www.Ihn.unihamburg.de/article/diachronic-narratology-example-ancient-greek-narrative [view date:12 Feb 2019] 